\title{
Intercalated nanosized MO2 (M: Sn, Ce) layers between CNTs and Pt or PtSn nanoparticles catalysts
}

\author{
Amel Tabet-Aoul, Mohamed Mohamedi \\ Energie, Matériaux et Télécommunications, Institut National de la Recherche Scientifique, 1650 Boulevard \\ Lionel-Boulet, Varennes, Quebec, J3X 1S2, Canada. \\ E-mail: mohamedi@emt.inrs.ca
}

\begin{abstract}
Direct ethanol fuel cells (DEFCs) is receiving enormous attention as alternative electrical energy conversion systems. This paper gives an outline on some recent advances achieved in our laboratory regarding the development of high performing anode for ethanol oxidation. We developed multi-components binderless hierarchically organized layer onto layer nanostructured catalysts comprising a carbon paper (CP, current collector)/carbon nanotubes (CNTs, conductivity enhancer)/catalyst promoter (MOx, M: Sn; Ce)/Pt-based (electrocatalyst). The main focus was how to lower the onset oxidation potential (OOP) of ethanol at $\mathrm{Pt}_{75} \mathrm{Sn}_{25}$ catalyst. Towards that aim, metal oxides such as $\mathrm{CeO}_{2}$ and $\mathrm{SnO}_{2}$ were sought as catalyst promoters. It has been discovered that intercalating a nanostructured layer of $\mathrm{SnO}_{2}$ between $\mathrm{CNTS}$ and $\mathrm{Pt}_{75} \mathrm{Sn}_{25}$ considerably lowered the OOP of ethanol and also increased the specific mass activity (SMA) at low potentials. Indeed, the OOP at the $\mathrm{CP} / \mathrm{CNT} / \mathrm{SnO}_{2} / \mathrm{Pt}_{75} \mathrm{Sn}_{25}$ was $210 \mathrm{mV}$ and $117 \mathrm{mV}$ negative relative to that delivered by $\mathrm{CP} / \mathrm{CNT} / \mathrm{Pt}$ and $\mathrm{CP} / \mathrm{CNT} / \mathrm{Pt}_{75} \mathrm{Sn}_{25}$, respectively confirming by that the promoting effect of $\mathrm{SnO}_{2}$ of the oxidation of $\mathrm{CO}$ at low potentials. The SMA determined at slow potential scan rate of $5 \mathrm{mV} / \mathrm{s}$ at $0.4 \mathrm{~V} \mathrm{vs}$. $\mathrm{Ag} / \mathrm{AgCl}$ revealed that $\mathrm{CP} / \mathrm{CNT} / \mathrm{SnO}_{2} / \mathrm{Pt}_{75} \mathrm{Sn}_{25}$ delivered an SMA of 1.2 times higher than that of the $\mathrm{CP} / \mathrm{CNT} / \mathrm{Pt}_{75} \mathrm{Sn}_{25}$ catalyst and 1.5 times greater than the one exhibited by the $\mathrm{CP} / \mathrm{CNT} / \mathrm{CeO}_{2} / \mathrm{Pt}_{75} \mathrm{Sn}_{25}$ catalyst.
\end{abstract}

\section{Indexing terms/Keywords}

Tin dioxide; ceria; platinum; platinum-tin alloy; carbon nanotubes; onset potential; ethanol electro-oxidation; direct ethanol fuel cells.

\section{Academic Discipline And Sub-Disciplines}

Electrochemistry

\section{SUBJECT CLASSIFICATION}

Physical-chemistry

\section{TYPE (METHOD/APPROACH)}

Synthesis and experimental study

\section{Council for Innovative Research}

\author{
Peer Review Research Publishing System
}

Journal: Journal of Advances in Chemistry

Vol. 3, No. 2 


\section{INTRODUCTION}

Ethanol is attractive as a biomass product, safe with high theoretical energy density $\left(8.0 \mathrm{kWh} \mathrm{kg}^{-1}\right)$ [1] and could make direct ethanol fuel cells (DEFCs) beneficial low-emission power sources. The complete ethanol oxidation reaction (EOR) to $\mathrm{CO}_{2}$ requires 12 electrons per ethanol molecule, which necessitates an electrocatalyst capable of activating $\mathrm{C}-\mathrm{H}, \mathrm{CO}$, and $\mathrm{C}-\mathrm{C}$ bonds. The breaking of the $\mathrm{C}-\mathrm{C}$ bond is not easily achieved at low temperature leading to low fuel cell efficiency [2]. To overcome that mechanistic challenge, Pt was often associated with other metals such as Ru [3-4], Re or Sn [5-9]. Among the electrocatalysts investigated $\mathrm{Pt} / \mathrm{Sn}$ catalysts somehow exhibited better electroactivity of oxidation of ethanol compared to other Pt-based electrodes.

Hitherto, at the $\mathrm{Pt} / \mathrm{Sn}$ catalysts, the entire oxidation of ethanol to $\mathrm{CO}_{2}$ at low potentials was not attained, instead producing only acetic acid and acetaldehyde as $\mathrm{C}-\mathrm{C}$ bond cleavage is probably the most complicated step. The multifunctional requirements of catalysts for the direct oxidation of ethanol which include the ability to activate $\mathrm{C}-\mathrm{H}$, $\mathrm{CO}$ and $\mathrm{C}-\mathrm{C}$ bonds, suggest that optimum performance will require ternary or even quaternary catalysts that not only oxidize ethanol at low potentials but also demonstrate current densities higher than those of pure Pt. However, preparation of three or four components electrocatalyst is tedious and require the optimisation of the composition of each component plus the content of carbon additive, a necessary conductivity enhancer in fuel cells electrodes. Such approach will necessitate an impressive number of synthesis experiments as well as the high cost that this entails. Consequently, taking into account the direct electrooxidation of ethanol in the fuel cells, the catalysts that could promote ethanol entire oxidation and displace the onset oxidation potential (OOP) to lower values are of the most importance.

Metal oxides (MOx) such as $\mathrm{SnO}_{2}$ [10-16] and $\mathrm{CeO}_{2}$ [17-22] showed improved electrocatalytic properties towards EOR when combined with noble metal nanoparticles such as Pt. Yet the role that $\mathrm{SnO}_{2}$ or $\mathrm{CeO}_{2}$ brings to Pt for the EOR is not yet understood. $\mathrm{SnO}_{2}$ 's role is believed to provide $\mathrm{OH}$ species to oxidize strongly bound intermediates, such as $\mathrm{CO}$ [1013]. $\mathrm{CeO}_{2}$ 's role has been supposed to be limited to improving Pt nanoparticles dispersion, or to supply oxygen atoms at lower potentials than that accomplished by Pt (bi-functional effect), or to change the electronic structure of Pt and lessens the potential of ethanol adsorption of $\mathrm{Pt}$ (the electronic effect) or both the bi-functional and electronic effects.

In recent years, we developed multi-components binderless hierarchically organized layer onto layer (lol) nanostructured catalysts comprising a carbon paper (CP, current collector)/carbon nanotubes (CNTs, conductivity enhancer)/catalyst promoter $(\mathrm{MOx}) / \mathrm{Pt}$-based (electrocatalyst). Electrocatalyst nanostructures that we have studied so far towards EOR are $\mathrm{CP} / \mathrm{CNT} / \mathrm{Pt}$ and $\mathrm{CP} / \mathrm{CNT} / \mathrm{Pt}_{75} \mathrm{Sn}_{25}$ [24], CP/CNT/SnO $/ 2$ Pt [16], CP/CNT/CeO $/ \mathrm{Pt}$ [23], and CP/CNT/SnO $2 / \mathrm{Pt}_{75} \mathrm{Sn}_{25}$ [25].

In our continuous effort to improve the catalytic performance of $\mathrm{CNT} / \mathrm{Pt}_{75} \mathrm{Sn}_{25}$ electrode with the principal objective of lowering further the OOP of ethanol, the first part of this paper presents for the first time the synthesis, characterization and electroactivity towards EOR of a CP/CNTs/CeO $/ \mathrm{Pt}_{75} \mathrm{Sn}_{25}$ nanostructured lol catalyst. The second part of this paper sums up advances we have achieved and present a comparative discussion of the performance of different electrocatalysts we studied until today. Based on the information gained, at the end, we present our opinion on the future directions to follow for a better design of efficient anode materials for DEFC.

\section{EXPERIMENTAL PROCEDURE}

\section{Carbon nanotubes synthesis}

CNTs were grown at $700^{\circ} \mathrm{C}$ by CVD using $\mathrm{Ni}$ as catalyst deposited by PLD onto a carbon paper (CP, Toray), acetylene (carbon source), hydrogen and argon (gas carrier) gases at flow rates of 30, 140 and 100 sccm, respectively. Full details regarding the synthesis and characterization of CNTs can be found in our previous publications [24].

\section{$\mathrm{CeO}_{2}$ and $\mathrm{Pt}_{75} \mathrm{Sn}_{25}$ synthesis}

Pt and $\mathrm{CeO}_{2}$ were synthesized by pulsed laser deposition (PLD) techniques, whereas $\mathrm{Pt}_{75} \mathrm{Sn}_{25}$ was fabricated using cross-beam laser deposition (CBLD). Pt, $\mathrm{CeO}_{2}$ and $\mathrm{Sn}$ targets of $99.99 \%$ of purity purchased from Kurt J. Lesker Co were used for the synthesis. Deposition was carried out by means of a pulsed KrF excimer laser $(\lambda=248 \mathrm{~nm}$, pulse width $=17 \mathrm{~ns}$, and repetition rate $=50 \mathrm{~Hz}$ ) under 2 Torr of $\mathrm{He}$ background pressure. $\mathrm{CeO}_{2}$ was deposited using a single beam with a laser fluence of $3.5 \mathrm{~J} \mathrm{~cm}^{-2}$ and 20000 laser pulses, wheras $\mathrm{Pt}_{75} \mathrm{Sn}_{25} \mathrm{was}^{2}$ deposited onto $\mathrm{CeO}_{2}$ layer by Cross-beam laser deposition (CBLD) (dual beam) using a laser fluence of $4 \mathrm{~J} \mathrm{~cm}^{-2}$ and 50000 laser pulses. Full details regarding the synthesis and characterization of $\mathrm{CeO}_{2}$ are reported elsewhere [23]. $\mathrm{Pt}_{75} \mathrm{Sn}_{25} \mathrm{deposited}$ onto CNTs were already fully characterized in our previous publication [24]. During $\mathrm{CeO}_{2}$ or $\mathrm{Pt}_{75} \mathrm{Sn}_{25} \mathrm{deposition}$ the targets are moved continuously across the laser beam (via a dual rotation and translation motion) to obtain a uniform ablation over the entire surface of the target. Prior to deposition, the chamber was evacuated by means of a turbo pump ( $4 \times 10^{-5}$ Torr). Helium was then introduced in the deposited chamber. In all cases, the substrate-to-target distance was fixed at $5 \mathrm{~cm}$ and all experiments were performed at room temperature. Full details about the PLD technique can be found elsewhere [26-27].

\section{Material characterization}

The surface morphology of the as-prepared samples was examined by means of a field emission scanning electron microscope (FESEM, JEOL-JSM-7401F) apparatus and a transmission electron microscopy (JEOL-JEM-2100F operating at $200 \mathrm{kV})$. 


\section{Electrochemical experiments}

The electrocatalytic properties were studied by voltammetry in a $0.5 \mathrm{M} \mathrm{H}_{2} \mathrm{SO}_{4}$ and in a mixture of $1 \mathrm{M} \mathrm{C}_{2} \mathrm{H}_{5} \mathrm{OH}+0.5 \mathrm{M}$ $\mathrm{H}_{2} \mathrm{SO}_{4}$ deaerated solutions. Preceding to the electrochemical measurements, the surface of the working electrode was cleaned electrochemically by potential cycling in $0.5 \mathrm{M} \mathrm{H}_{2} \mathrm{SO}_{4}$. Chronoamperometry (CA) was used for stability evaluation of the electrocatalysts in $1 \mathrm{M} \mathrm{C}_{2} \mathrm{H}_{5} \mathrm{OH}+0.5 \mathrm{M} \mathrm{H}_{2} \mathrm{SO}_{4}$ solution. Prior to each electrochemical measurement, dissolved oxygen was removed from the solution by bubbling argon for 20 to $30 \mathrm{~min}$. All electrochemical measurements were performed at room temperature using a three compartments electrochemical cell with the reference electrode and counter electrode being an $\mathrm{Ag} / \mathrm{AgCl}, 3 \mathrm{M} \mathrm{NaCl}$ and a platinum coil, respectively. The reference electrode was separated from the analyte solution by a Luggin capillary that is very close to the working electrode to minimize the ohmic drop. Data acquisition was conducted with a potentiostat/galvanostat Autolab from EcoChemie.

\section{RESULTS AND DISCUSSION}

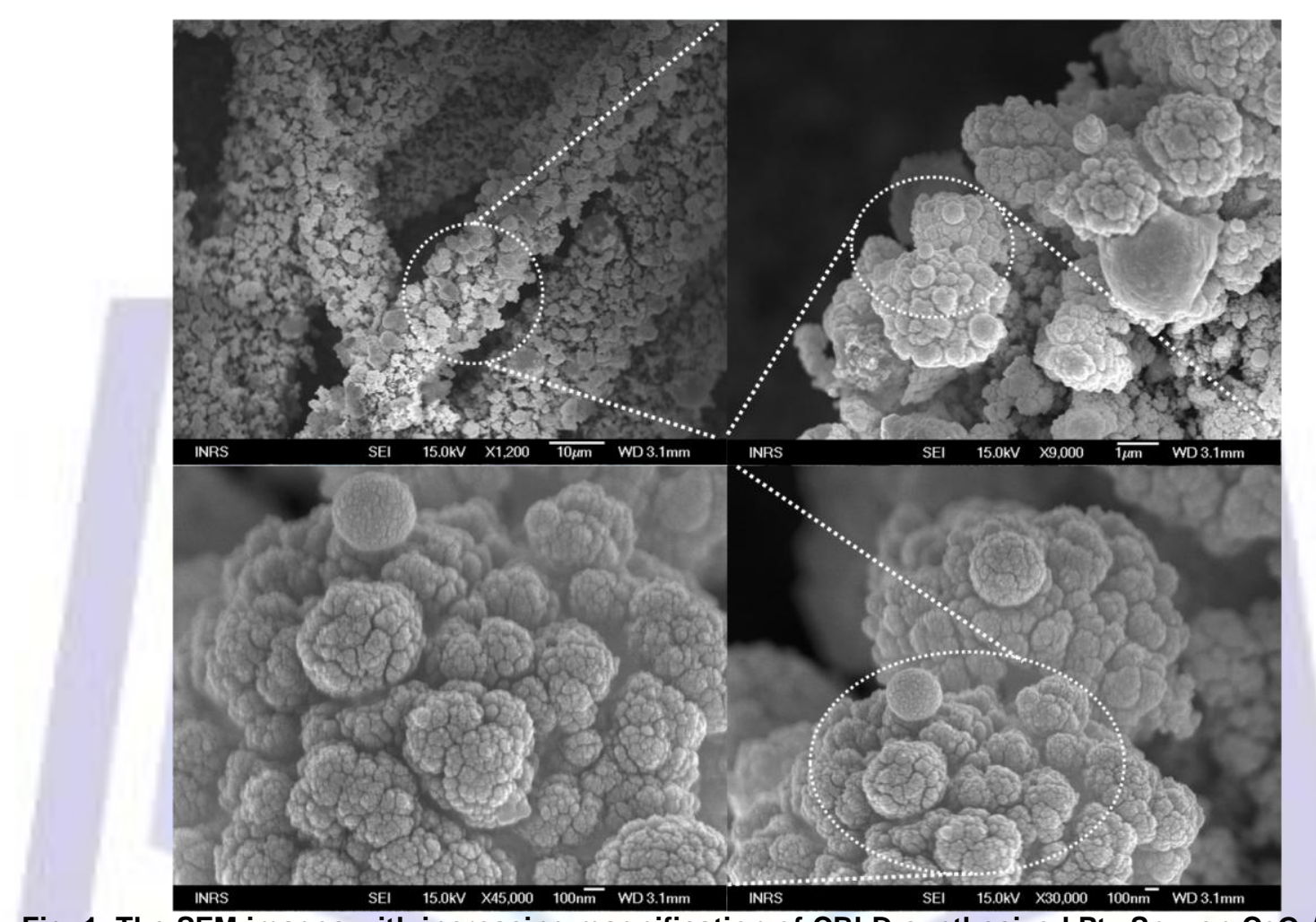

Fig. 1. The SEM images with increasing magnification of CBLD-synthesized $\mathrm{Pt}_{75} \mathrm{Sn}_{25}$ on $\mathrm{CeO}_{2} / \mathrm{CNT} / \mathrm{CP}$. 

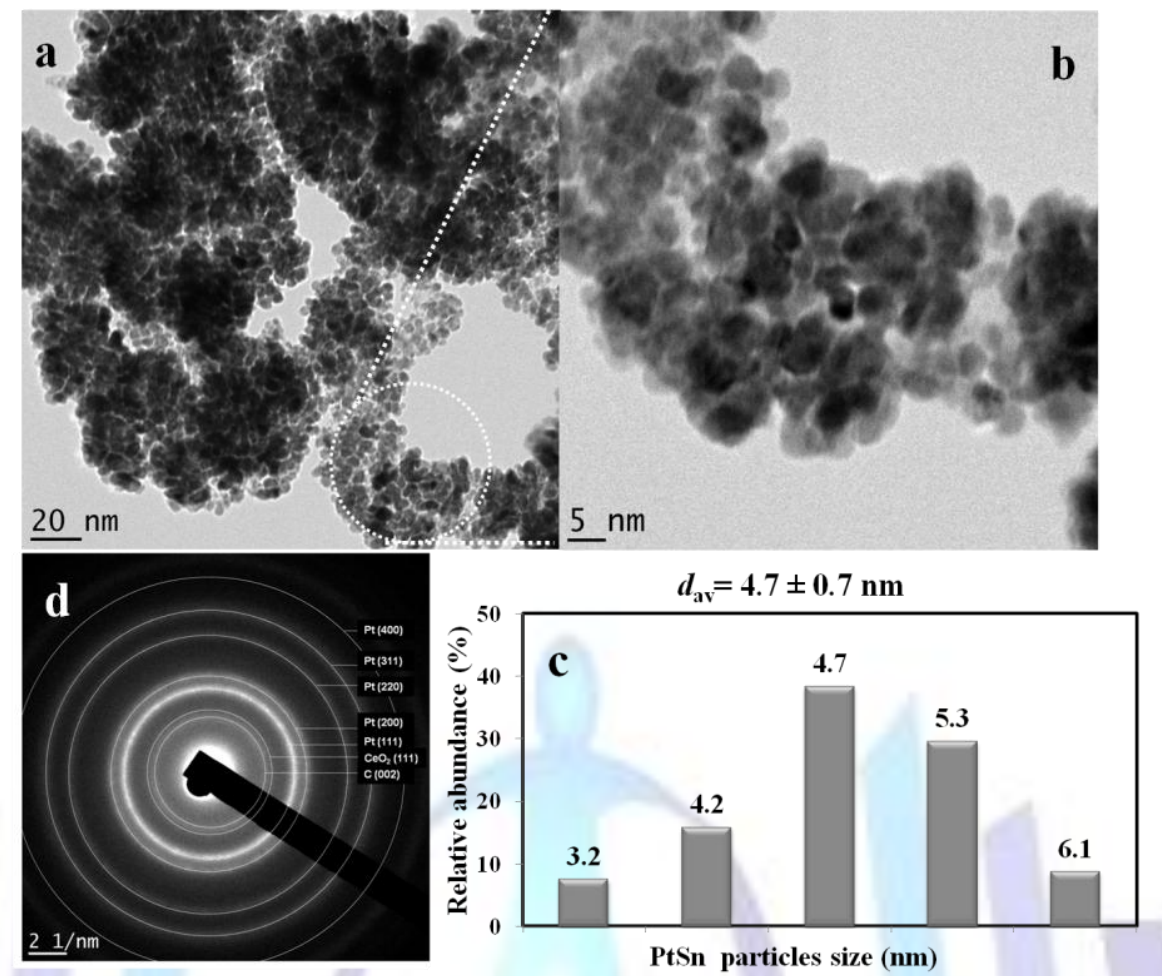

Fig. 2. (a) TEM, (b) HR-TEM, (c) particles size distribution histogram and (d) SAED patterns of $\mathrm{Pt}_{75} \mathrm{Sn}_{25}$ deposited onto $\mathrm{CeO}_{2}$.

\section{Characterization}

Fig. 1 shows FESEM images with increasing magnifications of $\mathrm{Pt}_{75} \mathrm{Sn}_{25}$ layer deposited by CBLD onto $\mathrm{CP} / \mathrm{CNT} / \mathrm{CeO}_{2}$. The images reveal that $\mathrm{Pt}_{75} \mathrm{Sn}_{25}$ film exhibits a highly porous morphology in which the particles assemble into cauliflower-like arrangements. The TEM and HR-TEM analyses of the $\mathrm{Pt}_{75} \mathrm{Sn}_{25}$ layer deposited onto $\mathrm{CeO}_{2} / \mathrm{CNT}$ are reported in Fig. $2 \mathrm{a}$ and Fig. $2 \mathrm{~b}$, respectively, which show that the $\mathrm{Pt}_{75} \mathrm{Sn}_{25}$ layer is made of high density of interconnected nanoparticles. The particle size distribution determined from the HR-TEM image of Fig. $2 \mathrm{~b}$ is very narrow ranging between 3 and $6 \mathrm{~nm}$ with a predominance around $4 \mathrm{~nm}$. The mean particle diameter is equal to $4.7 \pm 0.7 \mathrm{~nm}$ (Fig. 2c) which is close to $4.6 \mathrm{~nm}$ of $\mathrm{Pt}_{75} \mathrm{Sn}_{25}$ deposited onto CNTs [24]. The crystallographic orientation shown by SAED patterns (Fig. 2d) revealed lattice planes of (111), (200) (220) (311) and (400) of Pt, (111) of $\mathrm{CeO}_{2}$ and (002) of $\mathrm{C}$. Thus the morphology and the particle size is similar to $\mathrm{Pt}_{75} \mathrm{Sn}_{25}$ film prepared directly onto CNTs [24] and signifies that the underneath $\mathrm{CeO}_{2}$ layer had no effect on the morphology of $\mathrm{Pt}_{75} \mathrm{Sn}_{25} \mathrm{film}_{\mathrm{m}}$.

\section{Electroactivity of $\mathrm{CP} / \mathrm{CNT} / \mathrm{CeO}_{2} / \mathrm{Pt}_{75} \mathrm{Sn}_{25}$}

Figure 3 compares cyclic voltammograms (CVs) run at CP/CNT/Pt, CP/CNT/CeO $/ \mathrm{Pt}$ and $\mathrm{CP} / \mathrm{CNT} / \mathrm{CeO}_{2} / \mathrm{Pt}_{75} \mathrm{Sn}_{25}$ electrodes in $0.5 \mathrm{M} \mathrm{H}_{2} \mathrm{SO}_{4}$ deaerated solution. The $\mathrm{CVs}$ of $\mathrm{CP} / \mathrm{CNT} / \mathrm{Pt}$ and $\mathrm{CP} / \mathrm{CNT} / \mathrm{CeO}_{2} / \mathrm{Pt}$ were recorded within $0.25 \mathrm{~V}$ to $1.3 \mathrm{~V}$ potential range, whereas the $\mathrm{CVs}$ of $\mathrm{CNT} / \mathrm{CeO}_{2} / \mathrm{Pt}_{75} \mathrm{Sn}_{25}$ were recorded by setting the anodic limit to $0.50 \mathrm{~V}$ to circumvent the leaching of $\mathrm{Sn}$ that may occur at more positive potential [28-30]. Thus similar to CP/CNT/Pt and $\mathrm{CP} / \mathrm{CNT} / \mathrm{CeO}_{2} / \mathrm{Pt}$ electrodes, the $\mathrm{CVs}$ obtained at $\mathrm{CNT} / \mathrm{CeO}_{2} / \mathrm{Pt}_{75} \mathrm{Sn}_{25}$ presented as well the very well-known hydrogen adsorption $\left(\mathrm{H}_{\mathrm{ads}}\right)$ and desorption $\left(\mathrm{H}_{\text {des }}\right)$ peaks in the potential region of ca. -0.2 to $0 \mathrm{~V} \mathrm{vs}$. $\mathrm{Ag} / \mathrm{AgCl}$ [31-32]. Note that the CVs of Fig. 3 are displayed in terms of specific mass activity (SMA), i.e., the current density normalized to the Pt catalyst loading $\left(0.69 \mathrm{mg} / \mathrm{cm}^{2}\right)$. One can see that the SMA of CP/CNT/Pt and CP/CNT/CeO $/ \mathrm{Pt}$ and $\mathrm{CP} / \mathrm{CNT} / \mathrm{CeO}_{2} / \mathrm{Pt}_{75} \mathrm{Sn}_{25}$ are not significantly different from each other in $0.5 \mathrm{M} \mathrm{H}_{2} \mathrm{SO}_{4}$ electrolyte.

Fig. 4 shows a linear scan voltammogram (LSV) recorded with $10 \mathrm{mV} / \mathrm{s}$ scan rate at $\mathrm{CP} / \mathrm{CNT} / \mathrm{CeO}_{2} / \mathrm{Pt}_{75} \mathrm{Sn}_{25}$ electrode in $0.5 \mathrm{M} \mathrm{H}_{2} \mathrm{SO}_{4}+1 \mathrm{M} \mathrm{C}_{2} \mathrm{H}_{5} \mathrm{OH}$ solution. The LSV exhibited well defined characteristic ethanol oxidation shape in accord with the literature [30-33]. It should be noted that interpretation of ethanol oxidation related LSV is not straightforward owing the complexity of the reaction mechanism that involves several intermediates. For simplicity, in the LSV scan, within $-0.1 \mathrm{~V}$ and $0.15 \mathrm{~V}$ potential range, the current is very small, which indicates a slow reaction rate of ethanol oxidation caused by the poisoning of reaction itermediate $\mathrm{CO}$ that is strongly adsorbed on and blocks incessant adsorption and dehydrogenation of ethanol. At potentials higher than $0.15 \mathrm{~V}$, the current starts flowing indicating that adsorbed $\mathrm{CO}$ begins to be oxidatively removed. Significant rates of ethanol oxidation are observed only above ca. $0.4 \mathrm{~V}$ vs. $\mathrm{Ag} / \mathrm{AgCl}$. 


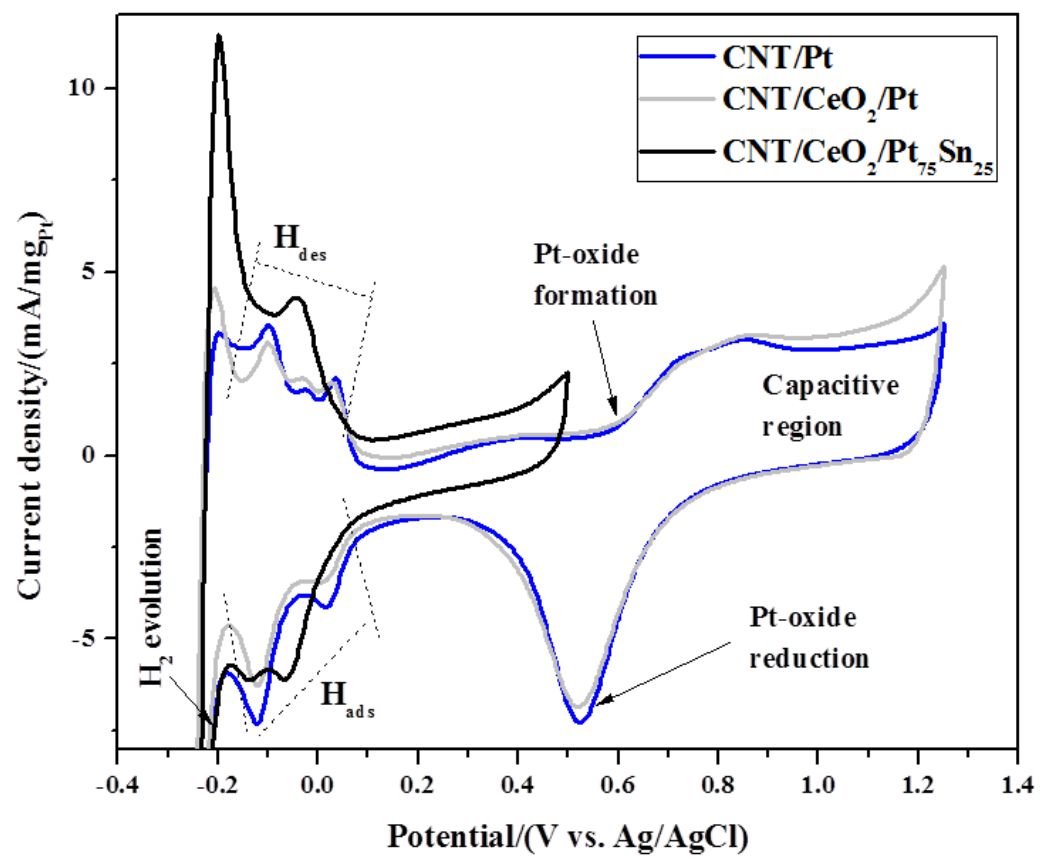

Fig. 3. Cyclic voltammetry in $0.5 \mathrm{M} \mathrm{H}_{2} \mathrm{SO}_{4}$-argon purged solution with the potential scan rate of $50 \mathrm{mV} / \mathrm{s}$ recorded at $\mathrm{CNT} / \mathrm{Pt}$ (blue curve), $\mathrm{CNT} / \mathrm{CeO}_{2} / \mathrm{Pt}$ (gray curve) and $\mathrm{CNT} / \mathrm{CeO}_{2} / \mathrm{Pt}_{75} \mathrm{Sn}_{25}$ (black curve) electrodes.

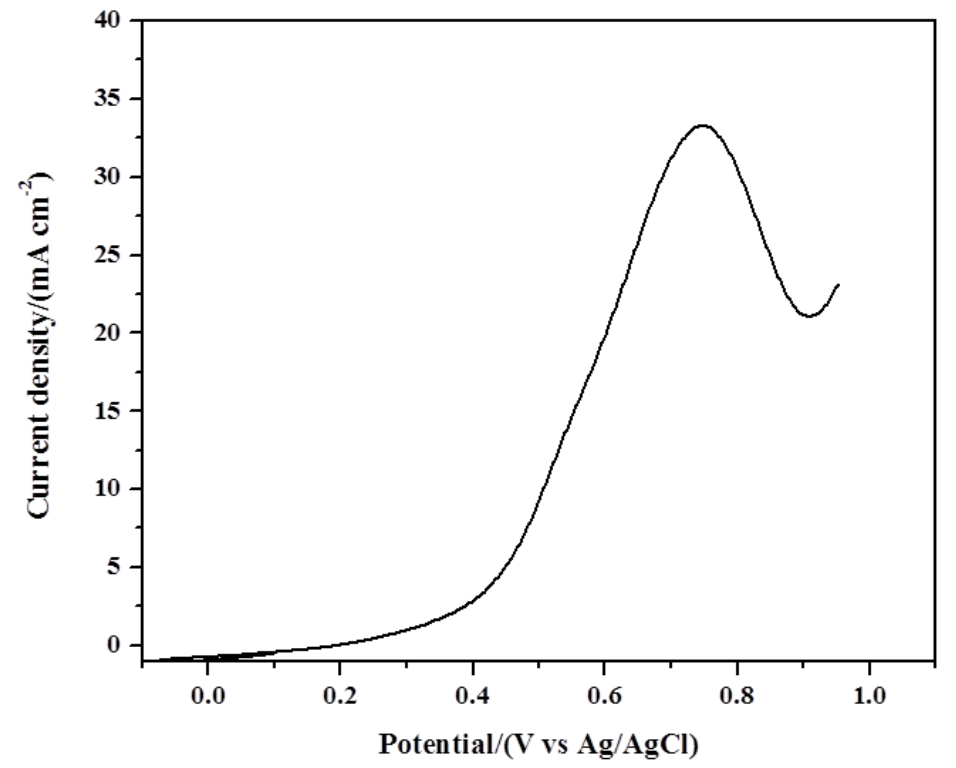

Fig. 4. Linear scan voltammetry in $0.5 \mathrm{M} \mathrm{H}_{2} \mathrm{SO}_{4}+1 \mathrm{M} \mathrm{C}_{2} \mathrm{H}_{5} \mathrm{OH}$-argon purged solution with the potential scan rate of $10 \mathrm{mV} / \mathrm{s}$ recorded at $\mathrm{CNT} / \mathrm{CeO}_{2} / \mathrm{Pt}_{75} \mathrm{Sn}_{25}$ electrode. 


\section{Comparative electroactivity of $\mathrm{CP} / \mathrm{CNT} / \mathrm{MO}_{2}(\mathrm{M}=\mathrm{Sn}, \mathrm{Ce}) / \mathrm{Pt}$ and $\mathrm{PtSn}$ electrodes}

Figure 5 compares LSVs of the EOR at the $\mathrm{CP} / \mathrm{CNT} / \mathrm{CeO}_{2} / \mathrm{Pt}_{75} \mathrm{Sn}_{25}$ catalyst structure developed here with several other catalyst structures such as CP/CNT/Pt, CP/CNT/Pt ${ }_{75} \mathrm{Sn}_{25}, \quad \mathrm{CP} / \mathrm{CNT} / \mathrm{SnO}_{2} / \mathrm{Pt}, \quad \mathrm{CP} / \mathrm{CNT} / \mathrm{CeO}_{2} / \mathrm{Pt}, \quad$ and $\mathrm{CP} / \mathrm{CNT} / \mathrm{SnO}_{2} / \mathrm{Pt}_{75} \mathrm{Sn}_{25}$. The OOP of ethanol defined as the potential value at which the anodic current starts to flow (as depicted by the insert of Fig. 5) is reported in Fig. 6a. Fig. 6a shows that the OOP delivered by CP/CNT/SnO $/ \mathrm{Pt}_{75} \mathrm{Sn}_{25}$ catalyst is $0.061 \mathrm{~V}$ which is significantly $210 \mathrm{mV}$ and $117 \mathrm{mV}$ negative with respect to that of CP/CNT/Pt electrode $(0.270$ V) and $\mathrm{CP} / \mathrm{CNT} / \mathrm{Pt}_{75} \mathrm{Sn}_{25}$ catalyst $(0.178 \mathrm{~V})$, respectively. Further important observation from Fig. 6a indicates that only catalysts containing $\mathrm{SnO}_{2}$ element exhibited the lowest OOP confirming by that the promoting effect of $\mathrm{SnO}_{2}$ of the oxidation of $\mathrm{CO}$ at low potentials. On the other hand, $\mathrm{CeO}_{2}$ seems to have neither lowered the OOP of the $\mathrm{Pt}_{75} \mathrm{Sn}_{25} \mathrm{nor}$ enhanced its SMA at low potentials.

Afterwards, the activity of each catalyst was compared by measuring the SMA at $0.4 \mathrm{~V} \mathrm{vs.} \mathrm{Ag/AgCl.} \mathrm{Fig.} 6 \mathrm{~b}$ shows that $\mathrm{CP} / \mathrm{CNT} / \mathrm{SnO}_{2} / \mathrm{Pt}_{75} \mathrm{Sn}_{25}$ delivered the highest current activity. The SMA at this electrode is $9.4 \mathrm{~mA} / \mathrm{mg}_{\mathrm{Pt}}$ that is 1.2 times higher than that of the $\mathrm{CP} / \mathrm{CNT} / \mathrm{Pt}_{75} \mathrm{Sn}_{25}$ catalyst $\left(7.81 \mathrm{~mA} / \mathrm{mg}_{\mathrm{Pt}}\right)$ and 1.5 times greater than the one exhibited by the $\mathrm{CP} / \mathrm{CNT} / \mathrm{CeO}_{2} / \mathrm{Pt}_{75} \mathrm{Sn}_{25}$ catalyst $\left(6.3 \mathrm{~mA} / \mathrm{mg}_{\mathrm{Pt}}\right)$. The results from voltammetry experiments indicate that intercalating a layer of $\mathrm{SnO}_{2}$ to the layered $\mathrm{CP} / \mathrm{CNT} / \mathrm{Pt}_{75} \mathrm{Sn}_{25}$ catalyst, not only promotes the electrooxidation of ethanol at low potentials but further enhances the SMA performance.

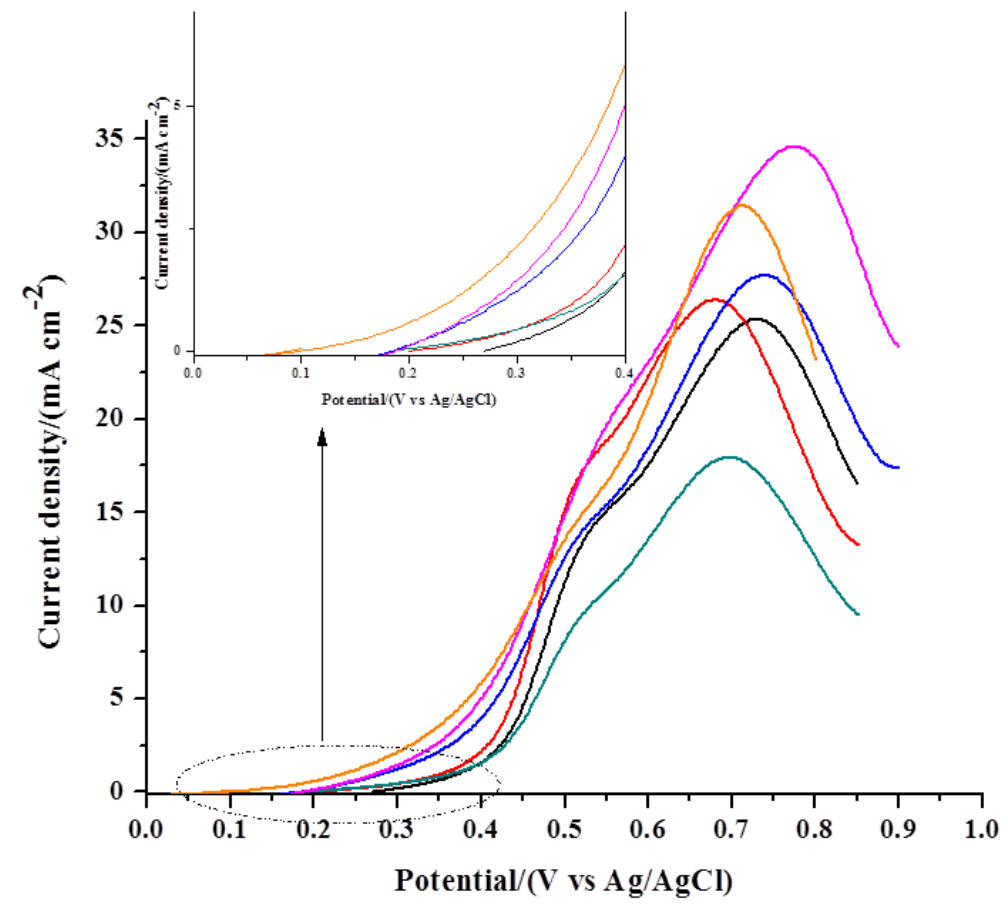

Fig. 5. LSV in $0.5 \mathrm{M} \mathrm{H}_{2} \mathrm{SO}_{4}+1 \mathrm{M} \mathrm{C}_{2} \mathrm{H}_{5} \mathrm{OH}$-argon purged solution with the potential scan rate of $5 \mathrm{mV} / \mathrm{s}$ recorded at: $\mathrm{CNT} / \mathrm{Pt}$ (black curve), $\mathrm{CNT} / \mathrm{CeO}_{2} / \mathrm{Pt}$ (red curve), $\mathrm{CNT} / \mathrm{CeO}_{2} / \mathrm{Pt}_{75} \mathrm{Sn}_{25}$ (blue curve), $\mathrm{CNT} / \mathrm{SnO} \mathrm{O}_{2} / \mathrm{Pt}$ (dark cyan curve), $\mathrm{CNT} / \mathrm{Pt}_{75} \mathrm{Sn}_{25}$ (magenta curve), and $\mathrm{CNT} / \mathrm{SnO}_{2} / \mathrm{Pt}_{75} \mathrm{Sn}_{25}$ (orange). Insert shows the onset oxidation potential (OOP) of ethanol. 

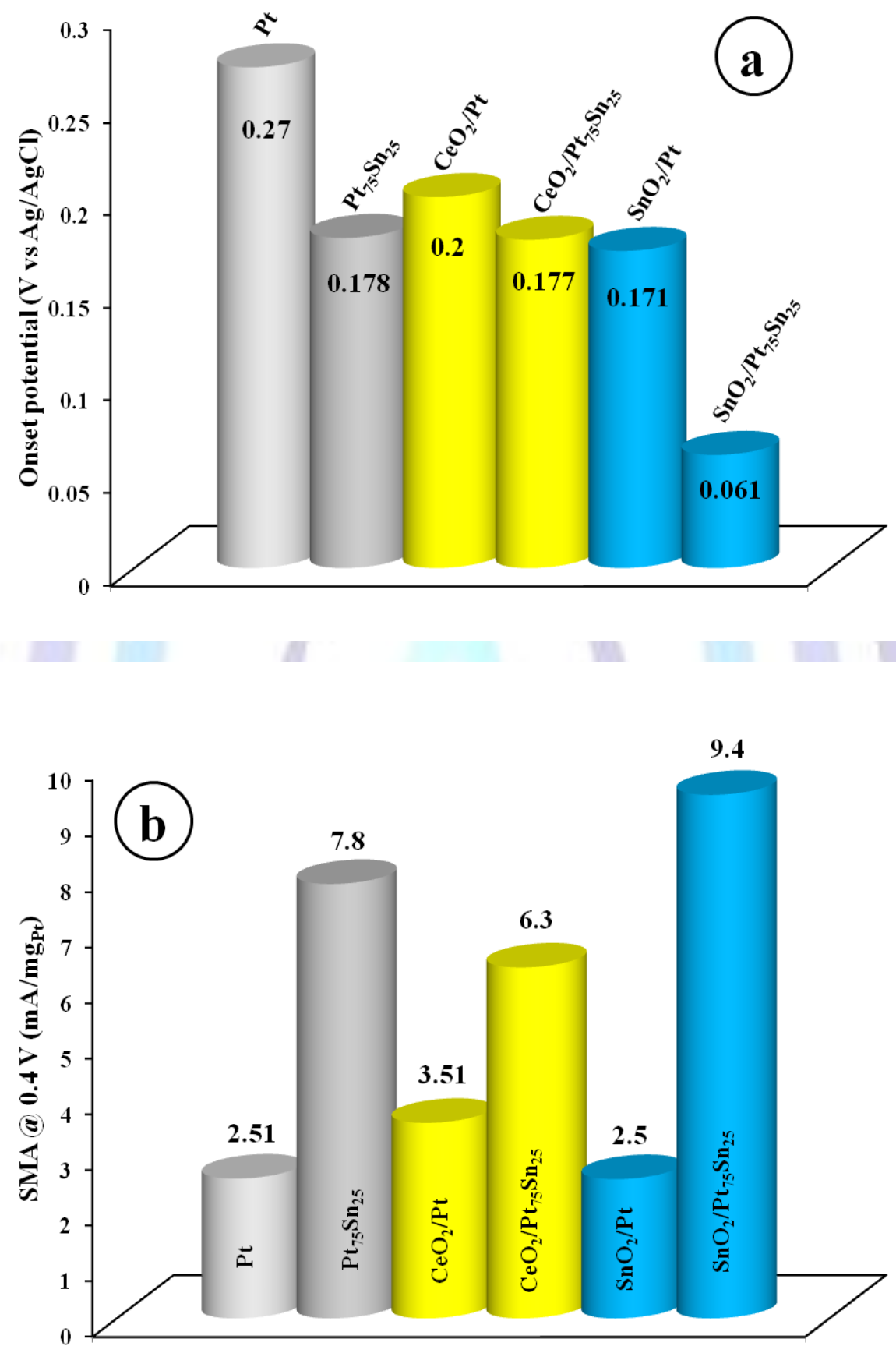

Fig. 6. (a) Comparative onset oxidation potential of ethanol extracted from LSVs recorded in $0.5 \mathrm{M} \mathrm{H}_{2} \mathrm{SO}_{4+1} \mathrm{M}$ $\mathrm{C}_{2} \mathrm{H}_{5} \mathrm{OH}$-argon purged solution with the potential scan rate of $5 \mathrm{mV} / \mathrm{s}$. (b) Comparative SMA estimated at $0.4 \mathrm{~V}$ vs. $\mathrm{Ag} / \mathrm{AgCl}$. The nature of the electrodes are labeled on the figure.

\section{CONCLUSIONS}

Oxidizing ethanol at low potentials is one of the enduring challenges of DEFCs, i.e., the foremost difficulty lies in the discovery of a catalyst being able to break the $\mathrm{C}-\mathrm{C}$ bond, forming small molecule fragments, which should be capable to be oxidized at quite low potentials. This paper resumes our recent advances into the development of nanostructured electrocatalysts for EOR. 
The main focus was how to lower the OOP of ethanol at Pt or $\mathrm{Pt}_{75} \mathrm{Sn}_{25}$ alloy. Towards that aim metal oxides such as $\mathrm{CeO}_{2}$ and $\mathrm{SnO}_{2}$ were sought as promoters. It has been discovered that intercalating a nanostructured layer of $\mathrm{SnO}_{2}$ between CNTs and $\mathrm{Pt}_{75} \mathrm{Sn}_{25}$ did not only significantly lowered the OOP of ethanol but also increased the SMA at low potentials. Indeed, the OOP was lowered by $210 \mathrm{mV}$ and $117 \mathrm{mV}$ relative to $\mathrm{Pt}$ and $\mathrm{Pt}_{75} \mathrm{Sn}_{25}$, respectively. This will have profound implications for DEFCs technology.

There is still room for improvement in SMA at low potentials. This can be done by further decreasing the amount of the catalyst or by optimizing the thickness of the $\mathrm{SnO}_{2}$ and $\mathrm{Pt}_{75} \mathrm{Sn}_{25}$ layers.

Finally, another variant of synthesis that deserves to be considered in the future is the simultaneous deposition of $\mathrm{SnO}_{2}$ or $\mathrm{CeO}_{2}$ and $\mathrm{Pt}_{75} \mathrm{Sn}_{25}$ catalysts onto CNTs. This would be interesting from both a fundamental and practical aspects to compare the electrocatalytic performance of such structures versus the layer onto layer structures.

\section{ACKNOWLEDGMENTS}

This work was supported by the Natural Sciences Engineering Research Council of Canada (NSERC), the Centre Québécois sur les Matériaux Fonctionnels (CQMF) and the FQRNT.

\section{REFERENCES}

[1] Hoogers, G. (2003), Fuel cell technology handbook, CRC Press, FL.

[2] Vigier, F., Coutanceau, C., Hahn, H., Belgsir, E.M. and Lamy, C. (2004), "On the mechanism of ethanol electrooxidation on Pt and PtSn catalysts: electrochemical and in situ IR reflectance spectroscopy studies", J. Electroanal. Chem., 563(1), 81-89.

[3] Neto, A.O., Giz, M.J., Ticianelli, E.A. and Gonzalez, E.R. (2002), "The Electro-oxidation of Ethanol on Pt-Ru and PtMo Particles Supported on High-Surface-Area Carbon”, J. Electrochem. Soc., 149(3), A272-A279.

[4] Spinacé, E.V., Neto, A.O., Vasconcelos, T.R. and Linardi, M. (2004), "Electro-oxidation of ethanol using PtRu/C electrocatalysts prepared by alcohol-reduction process”, J. Power Sources, 137(1), 17-23.

[5] Vigier, F., Coutanceau, C., Perrard, A., Belgsir, E.M. and Lamy, C. (2004), "Development of anode catalysts for a direct ethanol fuel cell", J. Appl. Electrochem., 34(4), 439-446.

[6] Lamy, C., Rousseau, S., Belgsir, E.M., Coutanceau, C. and Léger, J.M. (2004), "Recent progress in the direct ethanol fuel cell: development of new platinum-tin electrocatalysts ", Electrochim. Acta, 49(22-23), 3901-3908.

[7] Zhou, W.J., Song, S.Q., Li, W.Z., Zhou, Z.H., Sun, G.Q., Xin, Q., Douvartzides, S. and Tsiakaras, P. (2005), “Direct ethanol fuel cells based on PtSn anodes: the effect of Sn content on the fuel cell performance", J. Power Sources, 140(1), 50-58.

[8] Song, S.Q. and Tsiakaras, P. (2006), "Recent progress in direct ethanol proton exchange membrane fuel cells (DEPEMFCs)", Appl. Catal. B, 63(3-4), 187-193.

[9] Bommersbach, P., Mohamedi, M. and Guay, G. (2007), "Electrooxidation of Ethanol at Sputter-Deposited PlatinumTin Catalysts", J. Electrochem. Soc., 154(8), B876-B882.

[10] Jiang, L., Colmenares, L., Jusys, Z., Sun, G.Q. and Behm, R.J. (2007), "Ethanol electrooxidation on novel carbon supported $\mathrm{Pt} / \mathrm{SnO}$ x/C catalysts with varied Pt:Sn ratio", Electrochim. Acta, 53(2), 377-389.

[11] Pang, H.L., Lu, J.P., Chen, J.H., Huang, C.T., Liu, B. and Zhang, X.H. (2009), "Preparation of SnO ${ }_{2}-\mathrm{CNTS}_{\mathrm{T}}$ supported Pt catalysts and their electrocatalytic properties for ethanol oxidation", Electrochim. Acta, 54(9), 2610-2615.

[12] Salazar-Banda, G.R., Suffredini, H.B., Avaca, L.A. and Machado, S.A.S. (2009), "Methanol and ethanol electrooxidation on $\mathrm{Pt}-\mathrm{SnO}_{2}$ and $\mathrm{Pt}-\mathrm{Ta}_{2} \mathrm{O}_{5}$ sol-gel-modified boron-doped diamond surfaces", Mater. Chem. Phys., 117(2-3), 434-442.

[13] Hsu, R.S., Higgins, D. and Chen, Z. (2010), "Tin-oxide-coated single-walled carbon nanotube bundles supporting platinum electrocatalysts for direct ethanol fuel cells", Nanotechnology, 21(16), 165705.

[14] Higuchi, E., Miyata, K., Takase, T., and Inoue, H. (2011), "Ethanol oxidation reaction activity of highly dispersed $\mathrm{Pt} / \mathrm{SnO}_{2}$ double nanoparticles on carbon black", J. Power Sources, 196(4), 1730-1737.

[15] Zhang, H., Hu, C., He, X., Hong, L., Du, G. and Zhang, Y. (2011), "Pt support of multidimensional active sites and radial channels formed by $\mathrm{SnO}_{2}$ flower-like crystals for methanol and ethanol oxidation", J. Power Sources, 196(10), 4499-4505.

[16] Tabet-Aoul, A., Saidani, F., Rochefort, D. and Mohamedi, M. (2011), "Pulsed Laser Synthesis of SnO $\mathrm{St}_{2} \mathrm{Pt} \mathrm{Nann}^{-T h i n}$ Films onto Carbon Nanotubes and their Electrocatalytic Activity Towards Ethanol Oxidation", Int. J. Electrochem. Sci., 6(12), 6385-6397.

[17] Xu, C. and Shen, P.K. (2004), "Novel Pt/CeO $/$ C catalysts for electrooxidation of alcohols in alkaline media", Chem. Commun., 19, 2238-2239.

[18] Xu, C. and Shen, P.K. (2005), "Electrochemical oxidation of ethanol on $\mathrm{Pt}-\mathrm{CeO}_{2} / \mathrm{C}$ catalysts", J. Power Sources, 142(1-2), 27-29. 
[19] Díaz, D.J., Greenletch, N., Solanki, A., Karakoti, A. and Seal, S. (2007), "Novel Nanoscale Ceria-Platinum Composite Electrodes for Direct Alcohol Electro-Oxidation", Catal. Lett., 119 (3-4), 319-326.

[20] He, Q., Mukerjee, S., Shyam, B., Ramaker, D., Parres-Esclapez, S., Illán-Gómez, M.J. and Bueno-López, A. (2009), "Promoting effect of $\mathrm{CeO}_{2}$ in the electrocatalytic activity of rhodium for ethanol electro-oxidation", J. Power Sources, 193(2), 408-415.

[21] Neto, A.O., Linardi, M., dos Anjos, D.M., Tremiliosi-Filho, G. and Spinacé, E.V. (2009), "Electro-oxidation of ethanol on PtSn/CeO ${ }_{2}-\mathrm{C}$ electrocatalyst", J. Appl. Electrochem., 39(7), 1153-1156.

[22] Anderson, J., Karakoti, A., Díaz, D.J. and Seal, S. (2010), "Nanoceria-Modified Platinum-Gold Composite Electrodes for the Electrochemical Oxidation of Methanol and Ethanol in Acidic Media", J. Phys. Chem. C, 114(10), 4595-4602.

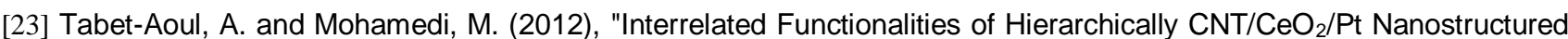
Layers: Synthesis, Characterization, and Electroactivity", Phys. Chem. Chem. Phys., 14(13), 4463-4474.

[24] Tabet-Aoul, A. and Mohamedi, M. (2012), "3D hierarchical cauliflower-like carbon nanotubes/platinum-tin nanostructure and its electrocatalytic activity for ethanol oxidation", J. Mater. Chem., 22(6), 2491-2497.

[25] Tabet-Aoul, A. and Mohamedi, M. (2013), "Synthesis of $\mathrm{Pt}_{75} \mathrm{Sn}_{25} / \mathrm{SnO}_{2} / \mathrm{CNT}$ Nanoscaled Electrode: Low Onset Potential of Ethanol Electrooxidation", J. Alloys and Compounds, 553(3), 113-118.

[26] Chrisey, D.B. and Hubler, G.K. (1994), Pulsed Laser Deposition of Thin Film, John Wiley \& Sons, NY.

[27] Irissou, E., Vidal, F., Johnston, T.W., Chaker, M., Guay, G. and Ryabinin, A.N. (2006), "Influence of an inert background gas on bimetallic cross-beam pulsed laser deposition”, J. Appl. Phys., 99(3), 034904-14.

[28] Siné, G., Foti, G. and Comninellis, Ch. (2006), "Boron-doped diamond (BDD)-supported Pt/Sn nanoparticles synthesized in microemulsion systems as electrocatalysts of ethanol oxidation", J. Electroanal. Chem., 595(2), 115124.

[29] Colmenares, L., Wang, H., Jusys, Z., Jiang, L., Yan, S., Sun, G.Q. and Behm, R.J. (2006), "Ethanol oxidation on novel, carbon supported Pt alloy catalysts-Model studies under defined diffusion conditions", Electrochim. Acta, 52(1), 221-233.

[30] Wang, H., Jusys Z. and Behm, R.J. (2006), "Ethanol electro-oxidation on carbon-supported Pt, $\mathrm{PtRu}$ and $\mathrm{Pt} \mathrm{S}_{3} \mathrm{Sn}$ catalysts: A quantitative DEMS study", J. Power Sources, 154(2), 351-359.

[31] Kinoshita, K., Ferrier, D.R. and Stonehart, P. (1978), "Effect of electrolyte environment and Pt crystallite size on hydrogen adsorption-V", Electrochim. Acta, 23(1), 45-54.

[32] Schmidt, T.J., Gasteiger, H.A., Stab, G.D., Urban, P.M., Kolb, D.M. and Behm, R.J. (1998), "Characterization of High- Surface- Area Electrocatalysts Using a Rotating Disk Electrode Configuration", J. Electrochem. Soc., 145(7), 2354-2358.

[33] Iwasita, T. and Pastor, E. (1994), "A dems and FT ir spectroscopic investigation of adsorbed ethanol on polycrystalline platinum", Electrochim. Acta, 39(4), 531-537.

\section{Author' biography with Photo}

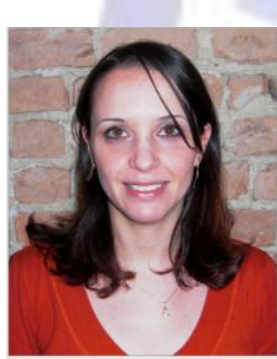

Amel Tabet-Aoul, Ph.D. is currently a postdoctoral fellow in the Institut National de la Recherche Scientifique, Universite d'Avant-garde. She received her Ph.D. in Engineering Science from the Université de Technologie de Belfort-Montbéliard (UTBM) and the University of Franche-Comté (UFC), France. Her main research interests are the synthesis, characterization and electro-chemical evaluation of nanomaterials and nanostructures for fuel cells and biomedical applications.

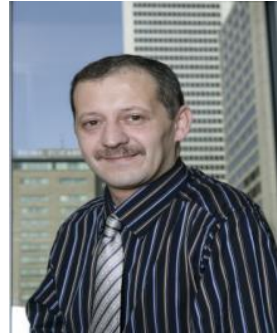

Mohamed Mohamedi received his Ph.D. in electrochemistry from the Institut National Polytechnique de Grenoble (INPG), France. He is a Professor-Researcher at INRS where he develops nanomaterials and micro-/nano energetic systems for electrochemical and biomedical applications. Dr. Mohamedi has published over 120 research articles and participated in more than 120 conferences. He is the recipient of the Tajima Prize from the International Society of Electrochemistry (ISE) and the Electrochemistry Communications Award 2007 for best cited paper related to micro fuel cells. He is an Editorial board member for several journals and is an active member of the American Nano Society, the Electrochemical Society and the ISE. 